Домашева Є. А.

ORCIDID: 0000-0003-2422-081X

Зозульов О. В.

канд. економ. наук, професор

ORCIDID: 0000-0001-7087-2080

Начіональний технічний університет України «Київський політехнічний інститут імені Ігоря Сікорського»

\title{
ВИЗНАЧЕННЯ СТРАТЕГІЇ ЗБУТУ В КІБЕРСЕРЕДОВИЩІ НА ПРОМИСЛОВОМУ РИНКУ
}

\section{DETERMINATION OF THE STRATEGY OF CAPACITY BUILDING IN THE CYBER ENVIRONMENT ON THE INDUSTRIAL MARKET}

Інформаційне середовище сприяє появі та розвитку нових технологій, удосконаленню існуючих бізнес-процесів. Базові інструменти трансформуються відповідно до вимог сучасності. Маркетологи адаптують навколишнє середовище з усе більшою орієнтацією на споживачів та максимальне задоволення їх потреб. Для успішної та ефективної діяльності y змінних ринкових умовах важливо розуміти вектори подальших дій, які формують стратегію. Об'єктом дослідження обрано стратегію збуту в кіберсередовищі. Робиться акиент саме на електронному збуті, шьо пов'язано з усе більшим розширенням меж digital простору. Для визначення власної стратегії необхідно розуміти, які існують їх типи, чим вони обумовлюються та які особливості характеризують кожен. Відсутність чіткої класифікачії ускладнює процес вибору. Для визначення критеріїв класифікаиії у статті розкрито ключові відмінності маркетингу в офлайн та онлайн середовищі за наступними критеріями: доступ до інформації, процес прийняття рішення, ивидкість $i$ відстань комунікаційного зв'язку, організація діяльності, комплекс маркетингу. Відображено схему збуту в кіберсередовищі з урахуванням наведених особливостей: залежно від обраної стратегії збуту створюється певний формат пропозииії, визначається спосіб комунікації, інструменти аналітики. На основі виділених критерїв: тип задіяного середовища, рівень утримання клієнта, суб'єкт реалізації дій, рімення для власного ресурсу, рішення для стороннього ресурсу - розроблено класифікацію стратегій збуту для учасників ринку В2В. Акцентується увага на певній ієрархічності вибору, коли кожен наступний крок залежить від попереднього. Даний факт обумовлює необхідність виділення якісних та кількісних детермінантів, які розглядаються при визначенні стратегії збуту. Оригінальний авторський погляд буде ціккавим спеціалістам у сфері маркетингу, торгівлі, підприємницької діяльності в ичілому.

Ключові слова: маркетинг в кіберсередовищі, схема збуту в кіберсередовищі, стратегія збуту в кіберсередовищі, детермінанти вибору стратегії, електронна комерція

The information environment promotes the emergence and development of new technologies, the improvement of existing business processes. Basic tools are transformed in accordance with the requirements of modern life. Marketers adapt the environment with an increasing focus on consumers and the maximum satisfaction of their needs. It is important to understand the vectors of further actions that form a strategy to make the activity successful and efficient in the variable market conditions. The object of research is the marketing strategy in cyberspace. The focus is on electronic distribution, which is connected with an ever-widening of the boundaries of digital space. To determine your own strategy, you need to understand what their types are, what they are conditioned, and what features each type characterizes. The lack of a clear classification 
complicates the selection process. To determine classification criteria, the article reveals the key differences in marketing in offline and online environments that based on the following criteria: access to information, decision-making process, speed and distance of communication, organization of activities, marketing complex. Taking into account the above features, the sales pattern in the cyberspace is reflected: depending on the chosen marketing strategy, a certain format of the offer is created, the way of communication, analytical tools is determined. On the basis of the selected criteria: the type of environment involved, the level of customer retention, the subject of the implementation of actions, decisions for own resources, solutions for a third-party resource - $a$ classification of marketing strategies for participants of the B2B market was developed. Attention is focused on a certain hierarchy of choice, when each next step depends on the previous one. This fact makes it necessary to identify the qualitative and quantitative determinants that are considered in determining the marketing strategy. The original author's opinion will be interesting to experts in the sphere of marketing, trade, business activity in general.

Keywords: marketing in cyberspace, the distribution scheme in the cyberspace, the distribution strategy in the cyberspace, the determinants of the choice of strategy, e-commerce

Вступ. Ми живемо в епоху, коли зміни стають глобальнішими i відбуваються в темпі, що постійно зростає. Нові технології, інструменти, популяризація електронної комерції, видозміна бізнес-процесів - сучасні тренди. У такий час важливо не втратити орієнтири, що визначають стратегією компанії. Одним 3 них $є$ перехід компаній у кіберсередовище. Такі зміни суттєво впливають на діяльність підприємств, зокрема на їх збутову стратегію, адже помітна трансформація каналів, їх множинність, інтеграція, гнучкість та адаптивність. Завдання маркетологів - розробити алгоритм дій в таких динамічних умовах.

Враховуючи відмінності маркетингу в офлайн і онлайн середовищі, модифіковану систему збуту 3 орієнтацією на кіберсередовище необхідно виділити детермінанти вибору стратегії та класифікаційні критерії, що систематизує та спростить процес розроблення стратегії збуту.

Останнім часом дана тема усе ширше розкривається у роботах науковців. Ілляшенко С. М., Апопій, В. В. - розкривають питання Інтернет-технологій та інтернет-торгівлі $[1,2,3]$, Шпилик С.В. - розглядає Інтернет як інструмент маркетингу [4], Зозульов О. В. - акцентує увагу на омніканальній стратегії збуту [5]. Також варто згадати таких авторів: Ковтун Е. О., Кравець В. М. Мамикін А.А., Кузнєцова Н. Г. - досліджують різні аспекти Інтернетмаркетингу.

Однак, варто відзначити, що недостатньо розкрито питання стратегії збуту в кіберсередовищі, зокрема не виділено можливих груп та їх особливостей. При цьому вибір стратегії - обов'язковий крок економічних суб'єктів для забезпечення ефективної ринкової діяльності.

Постановка завдання. Мета статті - розвиток методичних положень визначення стратегії збуту в кіберсередовищі на промислового ринку. Для цього необхідно розкрити такі аспекти:

- показати відмінності маркетингу в офлайн та онлайн середовищі; 
- відобразити схему збуту в кіберсередовищі;

- розробити класифікацію стратегій збуту в кіберсередовищі на промисловому ринку

- визначити детермінанти при виборі стратегії збуту.

Методологія. Теоретичною та методологічною основою дослідження послугували монографічний метод, метод аналізу та синтезу, дедукції, аналізу ієрархій, теоретичних узагальнень, групування. Інформаційною основою виступають наукові роботи вітчизняних і зарубіжних вчених, публікації у засобах масової інформації, Інтернет-ресурси.

Результати дослідження. Визначенню стратегії передує розкриття базових положень. Перш за все необхідно окреслити ключові відмінності традиційного маркетингу та маркетингу в Інтернеті (таблиця 1).

Таблиця 1- Ключові відмінності маркетингу в кіберсередовищі

\begin{tabular}{|c|c|}
\hline Критерій порівняння & Особливість кібер маркетингу \\
\hline \multirow[t]{2}{*}{ Доступ до інформації } & $\begin{array}{l}\text { Додаткова база даних - контакти осіб, що } \\
\text { заповнили форму на сайті, інтернет-платформі } \\
\text { тощо }\end{array}$ \\
\hline & Спрощення роботи з аналітикою \\
\hline \multirow{2}{*}{ Процес прийняття рішення } & $\begin{array}{l}\text { Більш прозорий процес прийняття рішення } \\
\text { споживачем (його можна відслідковувати) }\end{array}$ \\
\hline & $\begin{array}{l}\text { Споживач часто сам шукає необхідну } \\
\text { інформацію }\end{array}$ \\
\hline $\begin{array}{c}\text { Швидкість і відстань комунікаційного } \\
\text { зв’язку }\end{array}$ & $\begin{array}{l}\text { Швидке поширення інформації з великою } \\
\text { географією поширення (повідомлення «слідує» } \\
\text { за споживачем) }\end{array}$ \\
\hline Організація діяльності & $\begin{array}{l}\text { Спрощення процесу керування у великих } \\
\text { мережах }\end{array}$ \\
\hline \multirow{6}{*}{ Комплекс маркетингу } & $\begin{array}{l}\text { Представлення товару в режимі онлайн (економія } \\
\text { часу) }\end{array}$ \\
\hline & $\begin{array}{l}\text { Доповнення третього рівня товару - товар з } \\
\text { підкріпленням }\end{array}$ \\
\hline & Множинність каналів збуту, їх інтеграція \\
\hline & Можливість інтеграції різних каналів \\
\hline & $\begin{array}{l}\text { Більш чітке таргетування, простіше вийти на } \\
\text { цільову аудиторію }\end{array}$ \\
\hline & $\begin{array}{l}\text { Налаштування контенту згідно із запитами } \\
\text { споживачів (більш чіткий та релевантний посил) }\end{array}$ \\
\hline
\end{tabular}

На промисловому ринку наведені особливості більшою мірою впливають на функціонування мережевих утворень: спрощується та пришвидшується процес комунікацій, збільшуються темпи глобалізації, розширюється доступ до ринків інших країн. Функціонування бізнес-платформ дозволяє вийти на 
керівників та сформувати унікальну торгову пропозицію, виходячи 3 їх вимог та потреб.

Відмінності маркетингу в кіберсередовищі сприяють модифікації схеми збуту (рисунок). Прагнуть досягти прозорості та вимірюваності кожного етапу задля оцінки релевантних та хибних дій.

Як видно з рисунку, залежно від обраної стратегії збуту створюється певний формат пропозиції, визначається спосіб комунікації, інструменти аналітики.

Тому варто звернути увагу саме на критерії групування стратегій та навести характеристику кожної задля систематизації загальної картини (таблиця 2). 


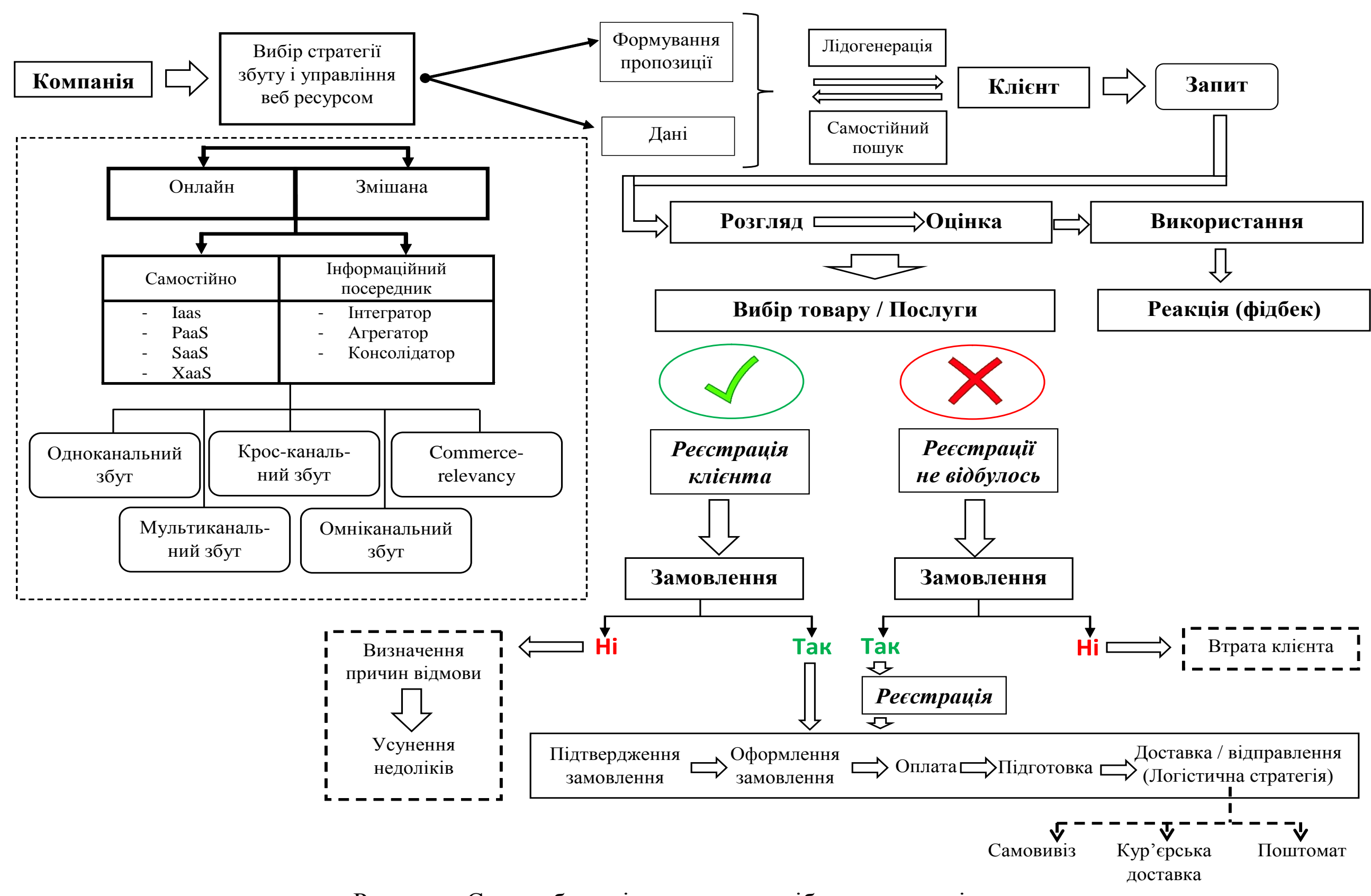

Рисунок - Схема збуту підприємства у кіберсередовищі 
Таблиця 2 - Класифікація стратегій збуту в кіберсередовищі

\begin{tabular}{|c|c|c|c|c|}
\hline №ח/П & $\begin{array}{l}\text { Критеріальна } \\
\text { ознака }\end{array}$ & Тип стратегій & $\begin{array}{l}\text { Чим визначається вибір } \\
\text { стратегії }\end{array}$ & Стисла характеристика \\
\hline 1 & 2 & 3 & 4 & 5 \\
\hline \multirow[b]{2}{*}{1.} & \multirow[b]{2}{*}{$\begin{array}{l}\text { Тип задіяного } \\
\text { середовища }\end{array}$} & Онлайн & \multirow{2}{*}{$\begin{array}{l}\text { - тип товару; } \\
\text { - тип споживачів; } \\
\text { - розмір фінансових ресурсів; } \\
\text { - стан ринку; } \\
\text { - діяльність конкурентів }\end{array}$} & Збут відбувається виключно через онлайн канали \\
\hline & & $\begin{array}{c}\text { Змішані (онлайн + } \\
\text { офлайн) }\end{array}$ & & $\begin{array}{l}\text { Використання одночасно онлайн та офлайн каналів } \\
\text { збуту }\end{array}$ \\
\hline \multirow{5}{*}{2.} & \multirow{5}{*}{$\begin{array}{c}\text { Рівень утримання } \\
\text { клієнта }\end{array}$} & Одноканальний збут & \multirow{5}{*}{$\begin{array}{l}\text { - тип споживачів; } \\
\text { - тип товару; } \\
\text { - складність комунікації; } \\
\text { - планований рівень утримання } \\
\text { клієнта; } \\
\text { - розмір фінансових ресурсів }\end{array}$} & $\begin{array}{l}\text { Використовується єдиний спосіб досягнення клієнтів. } \\
\text { Перевагою є зниження витрат, а також повний } \\
\text { контроль. }\end{array}$ \\
\hline & & $\begin{array}{l}\text { Мультиканальний } \\
\text { збут }\end{array}$ & & $\begin{array}{l}\text { Використовують декілька каналів збуту, які є слабо } \\
\text { інтегрованими між собою і конкурують за вибір } \\
\text { споживача [6]. }\end{array}$ \\
\hline & & Крос-канальний збут & & $\begin{array}{l}\text { Використовують декілька каналів збуту, які вже не } \\
\text { конкурують, а є взаємодоповнюючими. }\end{array}$ \\
\hline & & Омніканальний збут & & $\begin{array}{l}\text { Концепція схожа з 6рос канальним збутом, за винятком } \\
\text { того, що канали використовуються одночасно [5]. }\end{array}$ \\
\hline & & $\begin{array}{c}\text { Комерційна } \\
\text { релевантність }\end{array}$ & & $\begin{array}{l}\text { Головна ідея: подання релевантної інформації на } \\
\text { кожному каналі та для всіх учасників відносин [7]. }\end{array}$ \\
\hline 3. & $\begin{array}{c}\text { Суб’єкт реалізації } \\
\text { дій }\end{array}$ & Самостійно & $\begin{array}{l}\text { - етап життєвого циклу } \\
\text { підприємства; } \\
\text { - ІТ-компетенція; } \\
\text { - величина фінансових } \\
\text { ресурсів; } \\
\text { - прогнозований обсяг } \\
\text { продажів; } \\
\text { - схильність до ризику особи, } \\
\text { що приймає рішення }\end{array}$ & $\begin{array}{l}\text { Власник товару самостійно здійснює заходи з } \\
\text { організації збуту. }\end{array}$ \\
\hline
\end{tabular}


Продовження таблиці 2

\begin{tabular}{|c|c|c|c|c|}
\hline 1 & 2 & 3 & 4 & 5 \\
\hline 3. & $\begin{array}{l}\text { Суб’єкт реалізації } \\
\text { дій }\end{array}$ & $\begin{array}{c}\text { Інформаційний } \\
\text { посередник }\end{array}$ & & Власник товару звертається до сторонніх ресурсів для організації збуту. \\
\hline \multirow{4}{*}{4.} & \multirow{4}{*}{$\begin{array}{c}\text { Рішення для } \\
\text { власного ресурсу }\end{array}$} & IaaS & \multirow{4}{*}{$\begin{array}{l}\text { - ступінь ризику; } \\
\text { - необхідна } \\
\text { продуктивність та } \\
\text { надійність; } \\
\text { - ІТ-компетенція } \\
\text { клієнта; } \\
\text { - наявність IT- } \\
\text { інфраструктури, } \\
\text { обладнання; } \\
\text { - розмір компанії та } \\
\text { величина фінансових } \\
\text { ресурсів }\end{array}$} & $\begin{array}{l}\text { Інфраструктура як послуга - оренда обчислювальних ресурсів (сервери, } \\
\text { сховища даних, мережі, операційні системи), на які клієнт може } \\
\text { встановлювати будь-яке програмне забезпечення і додатки. Всі питання } \\
\text { адміністрування серверного та мережевого обладнання вирішує } \\
\text { провайдер, Але налаштування на рівні операційних систем і додатків в } \\
\text { них здійснює сам клієнт. }\end{array}$ \\
\hline & & $\mathrm{PaaS}$ & & $\begin{array}{l}\text { Платформа як послуга - в зону відповідальності провайдера входить вся } \\
\text { фізична інфраструктура, а також адміністрування на рівні операційних } \\
\text { систем. Клієнт же управляє додатками, розгорнутими на базі даної } \\
\text { інфраструктури. }\end{array}$ \\
\hline & & SaaS & & $\begin{array}{l}\text { Програмне забезпечення як послуга - клієнт не має доступу ні до } \\
\text { налаштувань на рівні інфраструктури, ні до конфігурації програмної } \\
\text { платформи. Він лише використовує готовий прикладний сервіс [8]. }\end{array}$ \\
\hline & & XaaS & & $\begin{array}{l}\text { Кожен компонент як сервіс - послуга, яка постачається через Інтернет } \\
\text { (окрім названих вище, моніторинг, зберігання тощо) [9]. }\end{array}$ \\
\hline \multirow[b]{2}{*}{5.} & \multirow[b]{2}{*}{$\begin{array}{l}\text { Рішення для } \\
\text { стороннього } \\
\text { ресурсу }\end{array}$} & Інтегратор & \multirow[t]{2}{*}{$\begin{array}{l}\text { - цілі клієнта; } \\
\text { - тип бізнесу; } \\
\text { - розмір фінансових } \\
\text { ресурсів; } \\
\text { - логістична стратегія }\end{array}$} & $\begin{array}{l}\text { IT-платформи, які не пропускають через себе ні замовлення, ні } \\
\text { фінансові потоки; інтернет-магазину не треба укладати з ними договір. } \\
\text { По суті, це майданчик, де зустрічаються інтернет-магазини і логістичні } \\
\text { компанії і можуть легко інтегруватися один з одним. Забезпечується } \\
\text { стандартизація життєвого циклу товарів. Нормуються статуси } \\
\text { замовлень, з’являється можливість зберігати і аналізувати дані. }\end{array}$ \\
\hline & & Агрегатор & & $\begin{array}{l}\text { Відноситься до веб-сайтів, які об'єднують певний тип інформації з } \\
\text { декількох джерел в Інтернеті. На відміну від інтеграторів, вони } \\
\text { пропускають через себе фінансові потоки, які надходять кожній } \\
\text { логістичній компанії. Їх основна мета - спростити процес взаємодії } \\
\text { інтернет-магазину з логістичною компанією і стандартизувати життвий } \\
\text { цикл замовлення. Використання агрегаторів відкриває інтернет- } \\
\text { магазинам можливість доставки по всій країні, що стимулює } \\
\text { електронний бізнес до швидкого розвитку. }\end{array}$ \\
\hline
\end{tabular}


Продовження таблиці 2

\begin{tabular}{|c|c|c|c|c|}
\hline 1 & 2 & 3 & 4 & 5 \\
\hline & & Консолідатор & $\begin{array}{l}\text { - цілі клієнта; } \\
\text { - тип бізнесу; } \\
\text { - розмір } \\
\text { фінансових } \\
\text { ресурсів; } \\
\text { - логістична } \\
\text { стратегія }\end{array}$ & $\begin{array}{l}\text { На відміну від агрегаторів і інтеграторів, вони } \\
\text { безпосередньо працюють з відправленнями. Є } \\
\text { сполучною ланкою між інтернет-магазинами і } \\
\text { логістичними компаніями. Консолідатори } \\
\text { забезпечують «першу милю» для магазину, після чого } \\
\text { об’єднують відправлення, які необхідно доставити в } \\
\text { одному напрямку, і передають вже сконсолідований } \\
\text { вантаж кур'єрській або транспортній компанії. За } \\
\text { рахунок цього інтернет-магазин істотно заощаджує на } \\
\text { доставці своїх замовлень в логістичні компанії [10]. }\end{array}$ \\
\hline
\end{tabular}

Вибір кожної з наведених стратегій відбувається послідовно, так як кожна наступна залежить від попередньої. Бачення керівників компанії, їх компетенція, специфіка ринку та товару, ресурси компанії тощо - все це впливає на стратегічний вибір.

Тому логічним вбачається визначення детермінант вибору стратегії збуту в кіберпросторі з виділенням якісних та кількісних показників (таблиця 3).

Таблиця 3 - Детермінанти визначення стратегій збуту в кіберпросторі

\begin{tabular}{|c|c|}
\hline Детермінант & Одиниця вимірювання \\
\hline \multicolumn{2}{|r|}{ Кількісні детермінанти } \\
\hline $\begin{array}{l}\text { Величина фінансових } \\
\text { ресурсів }\end{array}$ & Горошкові одиниці \\
\hline Вартість одного ліда & Горошкові одиниці \\
\hline $\begin{array}{l}\text { Швидкість входження } \\
\text { на ринок }\end{array}$ & дні, місяці \\
\hline $\begin{array}{l}\text { Прогнозований обсяг } \\
\text { продажів }\end{array}$ & грн / шт \\
\hline \multicolumn{2}{|r|}{ Якісні детермінанти } \\
\hline IT-компетенція & $\begin{array}{c}\text { Наявність та спеціалізація IT-відділу; відповідність тенденціям та } \\
\text { ринковій ситуації; бачення керівників }\end{array}$ \\
\hline $\begin{array}{l}\text { Розміщення цільової } \\
\text { аудиторії }\end{array}$ & Географічно розкидана / сконцентрована \\
\hline $\begin{array}{l}\text { Характеристики } \\
\text { продукту }\end{array}$ & $\begin{array}{c}\text { Товар / послуга; наявність конкурентних переваг; наявність } \\
\text { замінників та комплементарів }\end{array}$ \\
\hline ЕЖЦ компанії & Становлення, ріст, зрілість, спад \\
\hline $\begin{array}{l}\text { Загальна стратегія } \\
\text { компанії }\end{array}$ & $\begin{array}{c}\text { Бачення щодо власного розвитку та ринку в цілому, та вектор дій } \\
\text { компанії }\end{array}$ \\
\hline
\end{tabular}

Даний перелік не є вичерпним, адже вибір кожного учасника ринкових відносин обумовлюється особливостями бізнесу та цілями керівників.

Висновки. Наукова новизна отриманих результатів полягає в систематизації визначення стратегії збуту в кіберпросторі для чого було: 
- виділено ключові відмінності маркетингу в кіберсередовищі за такими критеріями: доступ до інформації, процес прийняття рішення, швидкість і відстань комунікаційного зв'язку, організація діяльності, комплекс маркетингу;

- відображено схему збуту в кіберсередовищі і показано місце стратегії в даному процесі;

- визначено критерії класифікацій стратегій збуту в кіберпросторі: за типом задіяного середовища, рівнем утримання клієнта, суб'єктом реалізації дій, рішення стосовно власного ресурсу чи інформаційного посередника;

- виділено детермінанти вибору стратегій на якісному та кількісному рівні.

Практичність даної роботи полягає в тому, що кожна група стратегій є своєрідним вектором розвитку компанії, які не можна залишати поза увагою.

Враховуючи подальші зміни ринкового середовища, зокрема кіберпростору, досліджувана тема буде потребувати ще більшої деталізації та доповнення.

\section{Література:}

1. Ілляшенко С. М. Сучасні тенденції застосування Інтернет-технологій у маркетингу [Текст] / С. М. Ілляшенко // Маркетинг і менеджмент інновацій. - 2011. - № 4. - Т. II. - С. 64 -74 .

2. Ілляшенко С. М. Перспективи та основні проблеми розвитку інтернет-торгівлі в Україні [Текст] / С. М. Ілляшенко, Т. Є. Іванова // Механізм регулювання економіки. - 2014. - № 3. - C. 72-81.

3. Апопій, В. В. Інтернет-торгівля: проблеми і перспективи розвитку [Текст] / В. В. Апопій // Регіональна економіка. - 2003. - № 1. - С. 25.

4. Шпилик С. В. Інтернет як ефективний маркетинговий інструмент сучасного підприємства / Світлана Василівна Шпилик // Галицький економічний вісник, - Т. : ТНТУ, 2015 - Том 49. - № 2. - С. 212-223. - (Маркетингові технології підприємств в сучасному науково-технічному середовищі).

5. Зозульов О. В. Формування омніканальної збутової стратегії підприємства / О. Зозульов, М. Левченко // Економічний вісник НТУУ «КПІ імені Ігоря Сікорського». - 2016. №13.

6. Multi-channel, Cross-channel, Omni-channel: What difference? [Електронний ресурс] // Marketing \& Growth Hacking Publication. - 2016. - Режим доступу: https://blog.markgrowth.com/multi-channel-cross-channel-omni-channel-what-is-the-difference3fc9f84c84b5.

7. Ben Rund Commerce Relevancy - The Next Generation of Omnichannel Commerce [Електронний ресурс]. - Режим доступу: https://blogs.informatica.com/2015/10/14/commercerelevancy-the-next-generation-of-omnichannel-commerce/\#ffid=u8Bjwkg0Reo

8. IaaS, PaaS или SaaS - Что из этого выбрать? [Електронний ресурс] // 1cloud - Режим доступу: https://1cloud.ru/services/private-cloud/iaas-paas-saas.

9. Rouse M. XaaS (Anything as a Service) [Електронний ресурс] / Margaret Rouse // WhatIs.com - Режим доступу: http://searchcloudcomputing.techtarget.com/definition/XaaSanything-as-a-service. 
10. Логистические услуги для интернет-магазинов: основной доклад 2017 [Електронний pecypc] // datainsight.ru. - 2017. C. 58-62 - Режим доступу: http://www.datainsight.ru/files/DILogistic2015-basereport.pdf. 